\title{
In 2532 Children we Report the Developmental Factors Influencing the Development of Atopic Diseases
}

\section{Cantani A*}

Pediatric Clinic, University “La Sapienza” Roma, Italy

*Corresponding author: Cantani A, Pediatric Clinic, University “La Sapienza” Roma, Italy

Received: December 01, 2016; Accepted: January 12, 2017; Published: January 19, 2017

\begin{abstract}
Allergic asthma and rhinitis, Atopic Dermatitis (AD), urticaria and gastrointestinal allergy, are common diseases of infants and children. It was recently estimated that $14 \%$ of children suffer from $A D, 8 \%$ from food allergy, and $12 \%$ from asthma [1,2]. The cumulated incidence of these diseases in adolescents has been estimated between $25-35 \%$, while the prevalence is about $20 \%$ [3]. The phenotypic expression of these illnesses varies extensively, being very mild in some cases, severe in many, and even life threatening in others. Specific $\lg E$ antibodies to foods and positive challenge tests to a number of food allergens are frequently present in children with these disorders. Cow's Milk (CM) appears to be the most common offending food both in gastrointestinal (vomiting, diarrhea, etc) and in cutaneous manifestations (urticaria and AD). About $0.5-7 \%$ of infants suffer from more or less adverse reactions to $\mathrm{CM}$ [4]. Babies particularly of atopic parents are at high risk of developing atopic diseases; therefore they are defined as at-risk babies [5-7].
\end{abstract}

\section{Introduction}

Atopy can interfere with a child's life at any age level, with varying severity. Intractable diarrhea due to CM Allergy (CMA) and AD are the most frequent in infants, where the clinical manifestations are more severe than in older children. Respiratory allergy and bronchial asthma can be serious illnesses in younger as well as in older children.

The desire to understand the multifaceted problem of atopy has stimulated the clinicians' and academicians' imagination for decades. Therefore interest has been focused on methods for the prediction and prevention of atopy [5-9]. Prevention of IgE-mediated diseases relies on the skill necessary to overcome the natural forces unceasingly working to sensitize humans to produce IgE antibodies. The phenotypic expression of allergic disease ensues from an elaborate interrelationship between the atopy-prone genetic constitution of a child and the experienced environment that surrounds it. Prevention of atopy could potentially be met by selectively interfering with the genetic and environmental factors that appear to be responsible in concert for the final phenotypic expression of atopy.

Human milk has been for centuries the only way of feeding human neonates. Since the beginning of this century CM formulas have become a common breast milk substitute when mother's milk was not available. During this century and especially in the last decade other formulas have been developed in order to reduce the antigen load and therefore the risk of sensitization.

In this paper we will briefly summarize recent data on the environmental factors triggering atopy. In addition, we will report recent knowledge on atopy prevention, also reviewing the so-called hypoallergenic formulas.

\section{Prediction of Atopy}

Prediction of atopic disorders is an important step and should be carried out by examining both genetic factors and neonatal conditions.

It has been known for centuries that heredity plays an important role in the development of atopy. A child with a negative family history still has about a 5-15\% risk of developing atopy. However, children with a parental history of atopic disease are at higher risk for the development of atopic symptoms. It has been found that if one parent is affected, the chances of an offspring being affected vary between 20 and $40 \%$. If both parents are affected the figure increases up to $40-60 \%$, and $50-80 \%$ if both show the same allergic manifestations. The risk of atopy in children who have an allergic sibling ranges between 25 and $35 \%[3,10]$. data:

The importance of genetic factors is also demonstrated by other

(I) children with positive family history for atopy develop allergic symptoms earlier than those with a negative family history [11],

(II) The higher the incidence the higher the number of affected subjects in the same family [3].

Notable differences exist in the so-called predisposition to atopic diseases, and further study appears to be necessary to better delineate the role played by genetic factors in the development of such disorders.

In many allergic patients total serum IgE levels are found to be elevated, and it has been shown that a high total serum IgE level in infants is often associated with the subsequent development of atopic symptoms. Therefore, it was proposed that the measurement of IgE by PRIST testing in infants or at birth would have a predictive value in the atopy development. Several investigators have demonstrated that the risk of developing atopic diseases was very high when the cord $\operatorname{IgE}$ level was above $0.5 \mathrm{IU} / \mathrm{ml}[5,8,9,12]$.

Our data shows that a newborn can be considered at risk for atopy when the cord IgE level is above $0.8 \mathrm{IU} / \mathrm{ml}$ [5]. We have also shown that neonates of non atopic parents $(0.032+0.87 \mathrm{IU} / \mathrm{ml}$ in the 
not atopic vs $\mathrm{O} .295+5.12 \mathrm{IU} / \mathrm{ml}$ in the atopic newborns, $\mathrm{p}<0.005$ ) [5]. Recent prospective studies have shown that the most accurate predictive results are obtained when family history and cord IgE levels are evaluated together $[9,12]$.

The notion that a neonate is at risk either by familial history or because of high total IgE levels or from both causes may help it to better handle the difficulties usually associated with a prevention program. Recent personal data obtained from a series of preterm babies of different gestational ages failed to show any significant differences in total IgE levels according to gestational age [13], thus suggesting that IgE synthesis is not increased during the last months of gestation.

\section{Environmental Factors influencing the Development of Atopic Diseases in Children}

It has been long known that a series of prenatal, neonatal and environmental factors such as season birth, home exposure to pets and tobacco smoke, viral infections, and dietary factors can be important in the phenotypic expression of atopy. We review hereafter the most important features of these factors.

\section{Prenatal Factors}

Several studies have suggested that infections during pregnancy and food or drugs administered to pregnant women are likely to lead to an increased risk of developing atopic disease in babies. It has been recently reported that the IgE concentration was higher in cord blood if the pregnant mothers had been administered progesterone. However, these elevated levels were not associated with an increased development of atopic disease in the infants, nor were newborn IgM levels related to subsequent allergies [14].

Can a baby be born allergic? Although the research in this field is scarce, some experimental and clinical observations have shown that the sensitization can occur during fetal life. As early as 1928, Ratner demonstrated intrauterine sensitization to $\mathrm{CM}$ proteins in Guinea pigs, and speculated on analogous sensitization in humans [15]. Subsequently, it was found that IgE synthesis occurs in utero as early as the 11th week of gestation [16]. It was also demonstrated that the fetus is capable of producing specific IgE antibodies to food allergens that were ingested by the mother during pregnancy. Antibodies to $\mathrm{CM}$ and soybean proteins have been detected in both the amniotic fluid and cord blood $[5,17]$. Since the mothers had no antibodies to these allergens, it follows that the antibodies had been synthesized by the fetus. It was therefore recommended to atopic women not to ingest, during pregnancy, excessive amounts of offending foods such as eggs and CM $[18,19]$. Very recently a randomized study performed in Sweden on a large population of pregnant women showed that a strict CM and egg free diet during the last three months of pregnancy had no effect on the development of atopy in the babies $[19,20]$.

Light and Wortley pointed out that a history of maternal asthma, symptomatic during pregnancy, is associated with an increased incidence of respiratory disease and/or jaundice in newborns [21].

Another factor in prenatal life influencing the development of atopy is the concentration of serum IgE in the mother's blood. Michel et al. found that the more allergic the mothers, the higher the $\operatorname{IgE}$ concentration in the cord blood of their newborn infants [22]. If a mother had a serum-IgE level of more than $100 \mathrm{IU} / \mathrm{ml}$, the serum $\operatorname{IgE}$ level of her newborn's cord blood was significantly higher than that of newborns whose mothers' serum IgE levels were less than $100 \mathrm{IU} /$ $\mathrm{ml}$. Conversely, Michel et al. found that the IgE levels of the infants' fathers did not appear to influence the newborn's cord blood IgE level [22].

The season of birth also seems to be a predisposing factor in atopy sensitization, as first demonstrated by Soothill et al. [23] who showed that the risk of developing a mite allergy was dependent upon the month of birth. Subsequently a significantly higher incidence of sensitization to pollens in childrens born in the March-May period and to mites in children born in the September-October period has been shown by several investigators. However, other studies have failed to confirm the above results [24].

We have examined 2532 children aged 1-14 years, all born in the Rome province. We showed that a significantly high proportion of children born during the June-September period had a Dermatophagoides pteronyssinus allergy $(\mathrm{p}<0.005)$, while those born during the March-May period had a grass-pollen sensitivity ( $\mathrm{p}<<0.005$ ), in the Rome province for the same age period of the children examined [24].

\section{Perinatal Factors}

Certain features of a child's perinatal history may significantly affect his chances of developing bronchial asthma. Accordingly a group of psychologists at the New York Hospital studied three groups of children to verify this hypothesis.

The first group consisted of 30 children with bronchial asthma seen for treatment in the Pediatric Allergy Clinic of the New York Lying-In Hospital. Each of the other two groups consisted of children without asthma selected from the birth records of the above hospital. They were matched with the asthmatic group by randomly selecting two babies from the same obstetrical unit. A greater frequency of neonatal complications was found among the asthmatic children. These included complications from either the mother or the baby in the perinatal period [25]. Therefore, a stressful birth significantly increases the chances of a child subsequently developing bronchial asthma.

\section{Early Surgery}

In early infancy, factors other than diet seem to "turn on" allergic diathesis. A study was carried out in order to follow-up the clinical impression of some pediatric allergists that early surgery might increase the risk of developing asthma or hay fever.

In the first part of the study, 115 children who had been operated on pyloric stenosis were followed-up and found to have had an aboveaverage prevalence of allergic disease. Of those who had undergone such an operation, 20\% developed bronchial asthma, 21\% developed hay fever and 36\% developed one or both of these conditions [26].

These figures were much higher than those found in household interviews in the Rochester Child Health Study investigation of a random sample of children 0-17 years of age in Monroe Country, USA. The study showed that $3.4 \%$ of the random sample of Rochester children had had asthma, $8.5 \%$ had had hay fever, and $10.6 \%$ had had one or both of these conditions [27]. In the second part of the study, 
Johnstone et al. reported on 47 boys who had a hernia repair and who were followed. They showed similar results. Of those who had undergone a herniorrhaphy in their first year of life, 34\% developed asthma, $21 \%$ developed hay fever and 55\% developed either one or the other [26].

In the third part of the study, 202 children from the Rochester Child Health Study, whose parents had reported that they had had asthma or hay fever, were investigated for evidence of early hospitalizations or surgery. Their parents reported significantly more hospitalizations. For the boys less than two years of age there were significantly more operations necessitating general anesthesia than for non-asthmatic children of the same age from the same random population group [26].

\section{Environmental Factors}

Another factor influencing the onset of asthma in early infancy is home exposure to many potent allergens such as mites, furred animal danders and pollens. Pets carry pollen and dust on their fur. When it is hot, most pets drool saliva since they do not sweat. This highly allergenic saliva dries and becomes an important part of what we call "house dust" in the home [28]. House dust mite appears to be the most common offending allergen in asthma, and early exposure to this allergen is associated with a significant increase of the risk of asthma at the age of 11 [29]. Sporik et al. concluded "we believe that increased exposure to dust mites and other indoor allergen may be a factor contributing to the recent increases in the morbidity and mortality associated with asthma" [29]. Previous studies have shown that early exposure to pets significantly influence the development of respiratory allergy to animal danders [30].

Morrison-Smith reported that atopy is less common in "developing" than in "developed" countries [31]. In a study of immigrants to Great Britain, he confirmed the lower incidence of bronchial asthma in children of African origin who were born outside Britain. Offspring of parents of African origin who were born in England, however, had at least as high a prevalence of atopic disease as non-African children. This suggests that the difference in the prevalence of asthma in African children was environmental rather than purely genetic [31].

Very recently we have shown that the prevalence of $\mathrm{AD}$ was significantly higher in Somali children living in Rome, in comparison with controls living in Somalia $(\mathrm{p}<0.001)$ and the age of weaning was significantly lower in Somali children living in Rome. This data again indicates that environmental factors may influence even the onset of $\mathrm{AD}[32]$.

\section{Infections}

As mentioned earlier, viral infections frequently trigger asthmatic attacks in children. During the last few years many studies have reported that several of these viruses, including Respiratory Syncytial Virus (RSV), parainfluenza (types 1-3), coronavirus, adenovirus, and cytomegalovirus may contribute to the development of allergic sensitization in the predisposed children. In children of atopic parents, the allergic sensitization accompanied by IgE synthesis manifested itself after viral upper respiratory infections, in coincidence with the specific antibody response to the virus. Increased levels of IgE antibodies have been shown in various viral infections $[33,34]$.

Previous studies have indicated that RSV-specific IgE antibodies are more persistently present and that high RSV-IgE titers are associated with increased concentrations of histamine in patients affected by RSV infections [35,36]. In addition, RSV and parainfluenza virus have the capacity to induce an IgE-specific antibody response in the airway, the presence and quantity of virus-specific IgE possibly being specifically related to the severity of symptoms [37].

In recent studies, BALB/c mice were infected intranasally with RSV and then exposed either to ragweed or ovalbumin. The results suggested that RSV infection can enhance the development of sensitization and the magnitude of antibody responses to other inhaled allergens found concomitantly in the respiratory tract during acute infection $[38,39]$.

There are several mechanisms by which viral infections enhance the antibody-specific responses to concomitantly inhaled allergens, thus favoring the development of an atopic disease. There could be alterations in the uptake and/or processing of mucosally introduced allergens during virus-induced inflammatory damage or preferential depression of IgE-specific T-suppressor cells, resulting in increased IgE production. There also could be enhancement of the IgEmediated histamine release associated with interferon production from the leukocytes of ragweed-allergic patients after viral infection, thereby altering vascular permeability; and possibly, the result Betaadrenergic blockade would preferentially stimulate IgE antibody formation. Moreover, viruses produce soluble factors that are chemotactic for basophils and that enhance histamine release from basophils and mast cells [40].

\section{Passive Smoking}

Among the environmental factors favoring the development of atopic disease, cigarette smoke plays a primary role. Evidence is steadily accumulating that there is an important relationship between parental smoking habits and atopic symptoms in children.

It has been observed that atopic symptoms start earlier in the nonsmoking children of parents who smoke [11]. Moreover, immunologic studies corroborate these findings. Reports of higher IgE levels in adult smokers [41] and in infants of smoking atopic parents [42] support the view that the immunologic abnormalities may be relevant. The issue of whether smoking acts by irritating the respiratory mucosa [43], which facilitates both the penetration of antigens and the spread of infection, or by a direct action on the immune system has yet to be resolved. Not only is tobacco smoke an irritant, but an increasing body of evidence also indicates that it predisposes to an increased susceptibility to respiratory viral infections.

This fits with recent data showing that adult smokers contract influenza more frequently. Studies have also shown a higher prevalence of recurrent respiratory infections in children of smoking parents [4345].Since these affections are asthmogenic, a vicious circle is started, especially in the winter months in which a greater viral transmission is facilitated: parents' smoking ---> viral respiratory infections ---> asthma in the child. As a result, only a drastic inhibition of smoking can interrupt this cycle. 
All these results concur to stress the importance of the environmental controls. Thus, there are grounds to forbid smoking not only in the allergic child's home, but also in the house of any child at risk for development of allergic disease. In addition, parents should not expose their children to passive smoking in other confined spaces, such as the family car.

\section{Allergy Prevention}

The possibility of preventing atopic diseases in high risk babies has been confirmed by several groups of investigators and we point out that in order to prevent atopic diseases in high risk babies they should be subjected not only to dietary measures, but also to environmental measures/ Our prevention program includes 1) environmental and 2) dietary manipulations such as follows:

1) Exclusive breast-feeding for the first six months of life; total avoidance of cow's milk, dairy products and eggs for the nursing mothers; selected weaning after the 6th month of life; cow's milk and dairy products gradually introduced after the 6th month and gluten shortly afterwards,

2) No smoking in the house; environmental controls for the elimination of house-dust mite; no pets in the house; day-care center attendance delayed to after the 3 rd year of life.

\section{Dietary Measures during Pregnancy}

As previously reported, several studies have suggested that antenal sensitization to food antigens may occur, however this phenomenon is quite rare. Antenal sensitization to different food antigens may be explained not only by the transfer of nutrients via the placenta, but also by the transfer of anti-idiotypic antibodies from the mother to the fetus.

In order to reduce the risk of antenal sensitization, different approaches have been suggested, aimed at modifyng the mothers' diet during pregnancy. It has been shown that the complete exclusion of milk and dairy products, eggs, fish, beef and peanuts during the pregnancy is associated with a reduced prevalence of $\mathrm{AD}$ and also a significant reduction in the severity score of the skin lesions [46]. However, two randomized studies failed to confirm the protective effect of dietary measures during pregnancy $[19,20]$. We would like to emphasize that in these studies the dietary measures were advised only in the last trimester of gestation and the mothers were encouraged to drink a casein hydrolyzed formula (Nutramigen) during the dietary restriction period. We can hypothesize that the short period of dietary restriction and the use of this formula may have influenced the negative results (see section on hydrolysate formulas).

\section{Prolonged Breastfeeding}

The preventive effect of breast-feeding on allergy development in high-risk infants has been shown in several prospective studies [6,7,47-49]. High risk babies should be exclusively breast-fed for the first six months of life, since human milk provides the infant not only with homologous proteins which are non-allergenic but also with a number of immunological factors which can prevent the absorption of macromolecules. Therefore, the preventive effect might be antigen non-specific.

\section{Dietary Measures during Lactation}

About 70 years ago American pediatricians documented that $\mathrm{AD}$ in exclusively breast-fed infants could be related to foods ingested by their mothers, and that the eczema cleared up when the mothers avoided the offending food(s). In addition, it was shown that exclusively breast-fed babies with $\mathrm{AD}$ had positive skin tests to foods never previously ingested. It was thus suggested that food antigens ingested by the mothers might pass into the breast milk, thus sensitizing the babies. This passage was first demonstrated by Stuart [50] who found that egg-whites are present in breast-milk up to a dilution of 10 . The complete exclusion of CM, eggs, fish and peanuts during breast feeding (six months) significantly reduced the prevalence of $\mathrm{AD}$ [46]. A prospective randomized study [51] demonstrated that the avoidance of CM, eggs and fish during the first three months of lactation was associated with a statistically significant reduction in the prevalence of AD at the age of three and six months and a significantly lower cumulative prevalence of atopic disease at four years of age.

We have investigated the sensitizing effect via breast milk of a partially-hydrolyzed (whey proteins) hypoallergenic formula. The formula was given to 39 nursing "high risk" mothers (400 $\mathrm{ml}$ daily) during the lactation period (six months) [52]. Another group of 39 nursing "high risk" mothers, who consumed $400 \mathrm{ml}$ of CM daily, served as control. There was no significant difference in the cumulative incidence of atopic diseases in the babies at one year of age according to the mothers' diet. However, the prevalence of babies at 6 and 12 months with specific IgE antibodies against the whey protein and with total IgE antibody levels more than 2 SD from the normal values for age were significantly higher $(\mathrm{p}=0.02)$ in the group of babies whose mothers received the hypoallergenic formula. This preliminary study showed that a partially hydrolysate formula not only still contains peptides which are able to sensitize high-risk babies via breast milk, but it seems even more sensitizing than CM [52].

Thus, it seems evident from the results of these studies that it is mandatory to avoid allergenic foods such as $\mathrm{CM}$, eggs, fish and peanuts throughout the breast-feeding period in order to prevent sensitization via breast milk. In addition, it seems from our preliminary data that $\mathrm{CM}$ protein hydrolysate formulas, when given to nursing mothers, may also sensitize the babies. We have shown in a multicenter study which was comprised 2.291 babies from several Italian maternity hospitals, that babies fed breast and/or soy-milk, and whose parents strictly followed the above shown environmental measures, had at one year of age a lower prevalence of atopic diseases $(5 \%)$ in comparison with bottle-fed babies (13\%). In addition, preventive measures were able to significantly postpone the onset and reduce the prevalence of allergy [53]. The results of this multicenter study confirm our previous studies which have shown that the prevalence of atopic diseases was significantly lower at age four years in children whose parents followed the prevention program [5-7, 48].

\section{Soy-Protein Formulas}

Since 1929 soy protein formulas have been used for feeding infants with CMA. They are well accepted by most infants, and their nutritional adequacy is comparable to that of $\mathrm{CM}$ formulas. As such, studies were performed on infants fed a soy formula exclusively 
during the first six months of life. They revealed no immunologic abnormalities or increase in infection morbidity [54]. Regarding the composition of soy protein formulas, they contain purified soy protein, fat is a mixture of vegetable oils, and carbohydrates are represented by maltodextrines, corn-starch or saccharose. Supplements of the daily recommended vitamin requirements, including vitamin $\mathrm{D}$, are added so that problems, similar to those found in premature infants, do not arise (Review in 55). More recently, carnitine has been added to some soy formulas in the same amount as that found in human milk to supplement the limited quantities stored by infants.

Carnitine, a nitrogen quaternary base present in meat and CM, is synthesized by the body from lysine and methionine. It allows the oxidation of long-chain fatty acids so that they can be transferred from the cytoplasm into the mitochondria, where they undergo Betaoxidation, producing energy. Infants cannot synthesize adequate quantities of carnitine from lysine and methionine because they lack the enzymes necessary for the biosynthesis. As a consequence carnitine deficiencies have been reported in infants fed soy formulas without added carnitine. They are recognised by subclinical or clinical manifestations resulting from the deficiency of the long-chain fatty acid utilization [55].

Soy protein formulas are used for different conditions including CMA, CM protein intolerance, lactose and galactose intolerance and in the management of infants with severe gastroenteritis. The use of such formulas for the prevention of atopy is rather controversial. Some studies have shown that soy formulas or breast-feeding supplemented with soy formula for the first six months of life significantly reduce the prevalence of atopic diseases [56-57]. In our studies, using a soy protein formula when breast-milk was not available, we did not see an increased prevalence of soy sensitization $[6,7,48,58]$. However, other studies failed to show any preventive effect of soy formulas $[59,60]$. These contradictory results may be explained by different factors. The number of babies studied by Kjellman and Johansson [59] was very low, being only 23 subjects in the study. The babies studied by Chandra et al. seemed to belong to a very select atopic-prone study group, with specific IgE and total cord blood IgE levels which were unusually high [60].

There is no doubt that soy proteins can induce sensitization and different allergic manifestations. However, during the last decade soy allergenicity has been frequently emphasized in the literature, without providing data on the true prevalence of soy allergy in different allergic diseases. Sampson has found that only 5\% of 204 patients with $\mathrm{AD}$ showed soy sensitivity has demonstrated by doubleblind placebo controlled challenge tests [61]. We have also confirmed this demonstrating that only $4 \%$ of 143 children with AD showed positive challenge tests to soy [62]. In addition, we reported a study of 21 infants with $\mathrm{AD}$ due to $\mathrm{CM}$ hypersensitivity, where a soy-protein formula was substituted in place of CM. Twenty of these infants showed improved skin lesions with the soy-protein formula [63].

Soy formulas are often poorly tolerated by infants with chronic diarrhea. Infact, intolerance to soy proteins can be a cause of chronic diarrhea often coexisting with CM intolerance. Some investigators consider soy intolerance to be caused by sensitivity to soy protein. However, neither a demonstration of soy protein-sensitivity nor the mechanisms of this intolerance have been claritied. It has been shown that a soy formula with lactose was useful for feedinginfants with chronic diarrhea and secondary multiple protein intolerance, including CM and soy proteins (Review in 55).

In conclusion soy formulas are nutritionally adequate and are well accepted by many infants. Many foods such as cakes, biscuits, ice cream, desserts and beverages can be made with soy protein formulas, thus offering children with CMA a varied diet. Although soy proteins can be sensitizing, they are less allergenic than CM proteins.

\section{Hydrolysate Formulas}

Hydrolyzed formulas have been developed with the aim of decreasing or eliminating the allergenicity of CM proteins. The use of these formulas is based on the premise that pre-digested protein, when fed as amino acids and peptides, provides nutrients in a non-antigenic form. Thus, protein hydrolysate formulas have been classified as "hypoallergenic".

These formulas are processed using two main technologies: heat denaturation and enzymatic hydrolysis to reduce the molecular weight of the peptides. The heat treatment alters the conformational epitopes, while the enzymatic hydrolysis affects the sequential determinants. These different technical procedures are necessary for obtaining an acceptable palatability. However, with the reduction of the antigenicity (peptides with very low MW) there is an associated reduction of the palatability. The allergenicity of these formulas is dependent on several factors such as the degree of digestion, the post-hydrolysis and the protein source itself. Extensively hydrolysate formulas are considered the most hypoallergenic, whereas partly hydrolysate formulas are considered less hypoallergenic and even dangerous to children with CMA $(64,65)$. The MW profiles of protein hydrolysates are an index of the extent of hydrolysis.

According to the protein source there are three types of hydrolysate formulas: bovine casein (Alimentum, Nutramigen, Pregestimil), bovine-whey (Alfa-Rè, Prophylac), and soy and bovinecollagen (Pregomin). In addition, a bovine-whey partly hydrolysate formula with lactose has been developed (Beba HA, which is called HA in Italy and Good Start HA in US).

More recently, a partially casein and whey-protein hydrolysate formula (Aptamil HA) has also been developed. This product seems to be more adequate nutritionally because it constats of $50 \%$ casein and $50 \%$ whey-protein. However, due to the less extensive hydrolysis, this formula should be given only for prevention and not for treatment of infants with CMA. All these formulas are supplemented with vegetable lipids. Alfa-Rè, Alimentum and Pregestimil also contain medium-chain triglycerides. All hydrolysate formulas, excepted Beba $\mathrm{HA}$, are lactose free, and all contain small amounts of carnitine. They are rather unpalatable (excepted Good Start) and for this reason the compliance is poor.

Because hydrolysate formulas are nutritionally adequate, infants generally gain weight until they refuse the formula because of its bad taste. However, caution should be taken when these formulas are given for prolonged periods because no data is available on nutritional assessment of infants fed exclusively with such formulas for several months. The only data available is from studies which have shown animal models that hydrolysate formulas do not elicit an IgG response nor a cutaneous passive anaphylaxis. In addition, infants fed 
casein hydrolysates during the first three months of life do not show IgG antibodies to the hydrolysate formula. This data strongly suggests that these formulas are not antigenic. However, they do contain peptides of MW greater than 2.500, which may elicit an IgE response in predisposed infants [65].

We initially reported [66] 5 cases of infants, aged 3-8 months (median 5 months) with an IgE-mediated CMA, who experienced anaphylactic reactions when first fed a small amount of a whey hydrolysate (Alfa-Rè). They all demonstrated positive skin test and RAST to both CM proteins and Alfa-Rè. Subsequently, these infants were all successfully fed a soy-protein formula without further consequences. This data showed that whey-hydrolysate formulas can trigger severe anaphylactic reactions in children with an IgEmediated CMA [66]. Later, other cases of anaphylactic reactionswere reported in infants with IgE-mediated CMA fed hydrolysate formulas [67-69]. Confirmation of this is by a recent study which demonstrated residual casein epitopesin all the hypoallergenic formulas tested: AlfaRè, Pregomin, Beba HA [65]. The above data strongly supports other studies [64] which showed that antibodies raised against a CM formula recognized epitopes displayed by peptides of other hydrolysate formulas: Pregomin, Alfa-Rè, Nutramigen, Pregestimil. It was also shown that hydrolysate formulas when injected into experimental animals induced cell-mediated immunity and that cross-reactivity exists also between IgE antibodies to CM and peptides of hydrolysate formulas, in this limb of the immune response. Hydrolysate formulas contain protein fractions which result in a specific IgE binding after incubation with serum samples from patients allergic to CM [65].

In conclusion, although the proteins of hydrolysate formulas have been processed by heat and enzymatic hydrolysis and therefore contain peptides of lower MW than the native protein source, the peptides still have allergenic capacity and can be recognized by the cell-bound IgE antibodies of a child allergic to CM. As shown by an elegant study, nine of fifteen children sensitive to $\mathrm{CM}$ and with a positive histamine release from mixed leukocytes also had a positive histamine release to at least one of five tested hypoallergenic formulas [70].

According to recent studies, extensively casein hydrolysate formulas are safer [71,72]. Generally, CM hydrolysate formulas are well tolerated by infants with gastrointestinal symptoms caused by $\mathrm{CM}$ intolerance and who do not have IgE antibodies to CM proteins.

Several groups of investigators have used these formulas (Nutramigen or HA) as breast milk substitute in high risk babies and although these studies have a short follow-up, the results seems to be very encouraging [73-75]. A recent issue of the Committee on Nutrition of the American Academy of Pediatrics states that no published, well controlled, double-blind studies exist to support the use of whey hydrolysates either for prophylaxis or treatment of infants with CM hypersensitivity. Limited clinical experience suggests that a whey hydrolysate formula may be an acceptable alternative to $\mathrm{CM}$ and soy protein formulas for infants intolerant, but not allergic, to CM [76]. We conclude that partly hydrolysate formulas and whey hydrolysate formulas should not be used in infants with IgE-mediated CMA. Further studies are needed to investigate the nutritional adequacy of hydrolysate formulas in babies fed exclusively such formulas for several months.

\section{Weaning}

Another important dietary preventive measure is selected weaning after the 6 th month of life. This has been shown to be a useful measure for atopy prevention [77]. However, weaning is potentially dangerous for the high-risk baby. Special care should be addressed when new foods are introduced into these infants' diet and offending foods such as eggs, fish, and peanuts should be further postponed.

\section{Conclusion}

According to previous and recent studies, prevention of atopic diseases in predisposed newborn babies seems to be worthwhile. Environmental and dietary manipulations should be addressed to "high-risk babies" in order to avoid, or post-pone the risk of sensitization, or to mitigate the clinical course of the atopic disease once established.

\section{References}

1. Youngh P. Asthma and Allergies: an optimistic future. US Department of Health and Human Services. Public Health Service. NIH Publication. 1980; 30: 388.

2. Burr ML, Butland BK, King S, Vaughan-Williams E. Changes in asthma prevalence: two surveys 15 years apart. Arch Dis Child. 1989; 64: 1452-1456.

3. Kjellman N-IM. Atopic disease in seven-year-old children. Incidence in relation to family history. Acta Paediatr Scand. 1977; 66: 465-471.

4. Host A. The influence of early allergen contact on the development of atopy in childhood. Allergologie. 1989; 12: 186.

5. Businco L, Marchetti F, Pellegrini G, Perlini R. Predictive value of cord blood IgE levels in "at risk" newborn babies and influence of type of feeding. Clin Allergy. 1983; 13: 503-508.

6. Businco L, Cantani A. Prevention of atopy: Current concepts and personal experience. Clin Rev Allergy. 1984; 2: 107-123.

7. Businco L, Cantani A, Meglio P, Bruno G. Prevention of atopy: results of long-term (7 months to 8 years) follow-up. Ann Allergy. 1987; 59: 183-186.

8. Bousquet J, Michel F-B. Prediction of allergic risk in infants. In Businco Luisa (ed), Advances in Pediatric Allergy. Amsterdam: Elsevier Science Publishers. BV. $1983 ; 55$.

9. Kjellman N-IM, Croner S. Cord blood IgE determination for allergy prediction-a follow-up to seven years of age in 1651 children. Ann Allergy. 1984; 53: 167171.

10. Lubs ML. Empiric risk for genetic counseling in families with allergy. J Pediatr. 1972; 80: 26-31.

11. Witting HJ, Mc Laughlin ET, Leifer KL, Belliot JD. Risk factors for the development of allergic disease: Analysis of 2190 patients records. Ann Allergy. 1978; 41: 84-88.

12. Magnusson CGM. Cord serum IgE in relation to family history and as predictor of atopic disease in early infancy. Allergy. 1988; 43: 241-251.

13. Betti $P$, Galli E, Cantani A et al. Le IgE nel sangue di cordone di neonati pretermine e a termine. Folia Allergol Immunol Clin. 1987; 34: 67.

14. Michel FB, Bousquet J, Greillier P, Robinet-Lévy M, Coulomb Y. Comparison of cord blood immunoglobulin $\mathrm{E}$ concentration and maternal allergy for the prediction of atopic diseases in infancy. J Allergy Clin Immunol. 1980; 65: 422-430.

15. Ratner B. A possible causal factor of food allergy in certain infants. Am J Dis Child. 1928; 36: 277.

16. Miller DL, Hirvonen T, Gitlin D. Synthesis of IgE by the human conceptus. J Allergy Clin Immunol. 1973; 52: 182-188.

17. Singer AD, Hobel CJ, Heiner DC. Evidence for secretory $\lg A$ and $\lg E$ in utero. J Allergy Clin Immunol. 1974; 53: 94. 
18. Chandra RK, Puri S, Suraraiya C, Cheema PS. Influence of maternal food antigen avoidance during pregnancy and lactation on incidence of atopic eczema in infants. Clin Allergy. 1986; 16: 563-569.

19. Falth-Magnusson K, Kjellman N-IM. Development of atopic disease in babies whose mothers were receiving exclusion diet during pregnancy - a randomized study. J Allergy Clin Immunol. 1987; 80: 868-875

20. Lilja G, Dannaeus A, Foucard T, Graff-Lonnevig V, Johansson SG, Oman $H$. Effects of maternal diet during late pregnancy and lactation on the development of atopic diseases in infants up to 18 months of age - in vivo results. Clin Exp Allergy. 1989; 19: 473-479.

21. Light W, Wortley G. Effect of maternal asthma on the newborn. J Allergy Clin Immunol. 1980; 65: 204.

22. Michel $\mathrm{F}$, Bousquet $\mathrm{J}$, Coulomb $\mathrm{Y}$ et al. Comparison of clinical and immunological parameters for the prediction of infants allergy. J Allergy Clin Immunol. 1980; 65: 167.

23. Soothill J, Stokes C, Turner M, Norman AP, Taylor B. Predisposing factors and the development of reaginic allergy in infancy. Clin Allergy. 1976; 6: 305319

24. Businco L, Cantani A, Farinella F, Businco E. Month of birth and grass pollen or mite sensitization in children with respiratory allergy: a significant relationship. Clin Allergy. 1988; 18: 269-274.

25. Salk L, Grelling B, Traus W, Dietric J. Perinatal complications in the history of the asthmatic children. Am J Dis Child. 1974; 127: 30-33.

26. Johnstone D, Roghmann K, Pless IB. Factors associated with the developmen of asthma and hay fever in children: the possible risks of hospitalization, surgery and anesthesia. Pediatrics. 1975; 56: 398-403.

27. Haggerty R, Rogmann K, Pless I. Child Health and the Community. New York: Wiley and Sons. 1975; 346.

28. Johnstone $D$. The natural history of allergic disease in nature. Ann Allergy. 1977; 38: 387-393.

29. Sporik R, Holgate ST, Platt-Mills TAE, Cogswell JJ. Exposure to housedust mite allergen (Der $\mathrm{pl}$ ) and the development of asthma in childhood. A prospective study. N Engl J Med. 1990; 323: 502-507.

30. Suoniemi I, Biorksten F, Haahtela P. Dependence of immediate hypersensitivity in the adolescent period on factors encountered in infancy. Allergy. 1981; 36: 263-268.

31. Morrison-Smith J. Skin tests and atopic allergy in children. Clin Allergy. 1973; 3: $269-275$.

32. Asseyr AF, Botan AA, Ziruolo MG, Businco L. Atopic dermatitis and breast feeding of Somali children living in Somalia and in Italy. Pediatr Allergy Immunol. 1991.

33. Bahna SL, Horwitz CA, Fiala M, Heiner DC. Changes in serum IgE and IgM levels in heterophil-antibody positive infectious mononucleosis (HA + IM). Pediatr Res. 1977; 1: 484.

34. Perelmutter L, Phipps P, Potvin L. Viral infections and IgE levels. Ann Allergy. 1978; 41: 158-159.

35. Welliver RC, Kaul TN, Ogra PL. The appearance of cell-bound IgE in respiratory-tract epithelium after respiratory-syncytial-virus infection. $N$ Engl J Med. 1980; 303: 1198-1202.

36. Welliver RC, Wong DT, Sun M, Middleton E Jr, Vaughan RS, Ogra PL. The development of respiratory syncytial virus specific $\operatorname{lgE}$ and release of histamine in nasopharingeal secretions after infection. N Engl J Med. 1981; 305: 841-846.

37. Welliver RC, Wong D, Sun M, McCarthy N. Parainfluenza virus bronchiolitis Arch Dis Child. 1986; 140: 34

38. Leibovitz E, Freihorst J, Piedra PA, Ogra PL. Modulation of systemic and mucosal immune responses to inhaled ragweed antigen in experimentally induced infection with respiratory syncytial virus implication in virally induced allergy. In Arch Allergy Appl Immunol. 1988; 86: 112-116.
39. Freihorst J, Piedra PA, Okamoto $\mathrm{Y}$. Effect of respiratory syncytial virus infection of the uptake of and immune response to other inhaled antigens. Proc Soc Exp Biol Med. 1988; 188: 191-197.

40. Ida S, Hooks JJ, Siraganian RP, Notkins AL. Enhancement of IgE-mediated release from human basophil by virus: role of interferon. J Exp Med. 1977; 145: 892-906.

41. Zetterstrom O, Osterman K, Machado L, Johansson SGO. Another smoking hazard: Raised serum IgE concentration and increased risk of occupational allergy. BMJ. 1981; 283: 1215-1217.

42. Kjellman NI-M. Effect of parental smoking on IgE levels in children. Lancet. 1981; 1: 993-994

43. Fergusson DM, Horwood LJ, Shannon FT. Parental smoking and respiratory illness in infancy. Arch Dis Child. 1980; 55: 358-361.

44. Kark JD, Lebiush M, Rannon L. Cigarette smoking as a risk factor for epidemic A (H 1 N 1) influenza in young men. N Engl J Med. 1982; 307: 1042-1046.

45. Colley JRT. Respiratory symptoms on children and parental smoking and phleg m production. Br Med J. 1974; 2: 201-204.

46. Chandra RK, Puri S, Hamed A. Influence of maternal diet during lactation and use of formula feeds on development of atopic eczema in high risk infants. BMJ. 1989; 299: 228-230.

47. Bjorkstén B. Does breast-feeding prevent development of allergy? Immunol Today. 1983; 4: 215-217

48. Businco L, Marchetti F, Pellegrini G, Cantani A, Perlini R. Prevention of atopic disease in "at-risk newborns" by prolonged breast-feeding. Ann Allergy. 1983; 51: 296-299.

49. Saarinen UM. Prophylaxis for allergic disease: Role of infant feeding. Clin Rev Allergy. 1984; 2: 151-167.

50. Stuart HC. The excretion of foreign protein in human milk. AJDC. 1923; 25 : 135.

51. Hattevig G, Kjellman B, Sigurs N, Bjorkstén B, Kjellman N-IM. The effect of maternal avoidance of eggs, cow's milk and fish during lactation upon allergic manifestations in infants. Clin Exp Allergy. 1989; 19: 27-32.

52. Businco L, Cantani A. Prevention of childhood allergy by dietary manipulations. Clin Exp Allergy. 1990; 3 9-14.

53. Businco L, Bruno G, Giampietro PG, Cantani A. Results of a multicenter study on the prevention of atopy in "at-risk" babies. I Allergy Clin Immunol. 1991; 87: 176 .

54. Businco L, Bruno G, Grandolfo MG, Novello F, Fiore L, Amato C. Response to poliovirus immunization and type of feeding in babies of atopic families. Pediatr Allergy Immunol. 1990; 1: 60.

55. Businco L, Rubaltelli F. Management and prevention of cow's milk allergy in infants. Wyeth-Ayerst Nutr Semin Ser. 1989; 1: 41.

56. Johnstone DE, Dutton AM. Dietary prophylaxis of allergic disease in children. N Engl J Med. 1966; 274: 715.

57. Matthew DJ, Taylor B, Norman PA, Turner MW, Soothill JF. Prevention of eczema. Lancet. 1977; 1: 321

58. Businco L, Cantani A, Bruno G. Results of dietary and environmental measures for the prevention of atopy in "at-risk" babies. In Chandra RK (ed) Food Allergy. St John's: Nutrition Research Education Foundation. 1987; 361.

59. Kjellman N-IM, Johansson SGA. Soy versus cow's milk in infants with biparental history of atopic disease: development of atopic disease and immunoglobulins from birth to 4 years of age. Clin Allergy. 1979; 9: 347-358.

60. Chandra RK, Singh G, Shridhara B. Effect of feeding whey hydrolysate, soy and conventional cow milk formulas on incidence of atopic diseases in high risk infants. Ann Allergy. 1989; 63: 102-106.

61. Sampson HA. The role of food hypersensitivity and mediator release in atopic dermatitis. J Allergy Clin Immunol. 1988; 81: 635-645. 
62. Giampietro PG, Ragno V, Daniele S, Cantani A, Ferrara M, Businco L. Soyhypersensitivity in children with food allergy. Ann Allergy 1992; 69: 143-146.

63. Cantani A, Ferrara M, Ragno V, Businco L. Efficacy and safety of a soyprotein-formula for feeding babies with atopic dermatitis and cow's milk hypersensitivity. Eur Rev Med Pharmacol Sci. 1990; 12: 311.

64. Strobel S, Fairclough LM. Whole cow's milk versus hydrolysed infant formulae: analysis of systemic immune responses and antigenic crossreactivities. Food allergy in infancy and chilhood. Berlin: Springer- Verlag. 1989; 158.

65. Bauer CP. The binding capacity of Ige to hypoallergenic nutrients. Food allergy in infancy and childhood. Berlin: Springer-Verlag. 1989; 167.

66. Businco L, Cantani A, Longhi MA, Giampietro PG. Anaphylactic reactions to a cow's milk whey protein hydrolysate (Alfa-Ré, Nestlé) in infants with cow's milk allergy. Ann Allergy. 1989; 62: 333-335.

67. Bock SA. Probable allergic reaction to casein hydrolysate formula (letter). J Allergy Clin Immunol 1989; 84: 272.

68. Ellis MH, Short JA, Heiner DC. Anaphylaxis after ingestion of a recently introduced hydrolyzed whey protein formula. J Pediatr. 1991; 118: 74-77.

69. Saylor JD, Bahna SL. Anaphylaxis to casein hydrolysate formula. J Pediatr. 1991; 118: 71-74.
70. Lau S, Wahn U. How allergenic are "hypoallergenic" formulas? Food allergy in infancy and childhood. Berlin: Springer-Verlag. 1989; 173

71. Sampson HA, Bernhisel-Broadbent J, Yang E, Scanlon SM. Safety of casein hydrolysate formulas in children with cow's milk allergy. J Pediatr. 1991; 118 520-525.

72. Ragno V, Giampietro PG, Bruno G, Businco L. Allergenicity of 3 cow's milk proteins HFs in children with cow's milk allergy.

73. Schmidt E, Eden-Kohler J. International experience with a new hypoallergenic formula, Federal Republic of Germany. Food intolerance in children. New York: Raven Press. 1989; 279.

74. Vandenplas $\mathrm{Y}$, Loeb $\mathrm{H}$. A clinical trial with a new hypoallergenic formula. Food intolerance in children. New York: Raven Press. 1989; 283.

75. Zeiger RS. Prevention of food allergy in infancy. Ann Allergy. 1990; 65: 430.

76. AMA Committee on Nutrition. Hypoallergenic infant formulas. Pediatrics. 1989; 83: 1068

77. Saarinen UM, Kajosaari M, Backman A, Siimes MA. Prolonged breastfeeding as prophylaxis for atopic disease. Lancet 1979; 2: 163-169.
Austin J Allergy - Volume 4 Issue 1 - 2017

Submit your Manuscript | www.austinpublishinggroup.com

Cantani. (C) All rights are reserved
Citation: Cantani A. In 2532 Children we Report the Developmental Factors Influencing the Development of Atopic Diseases. Austin J Allergy. 2017; 4(1): 1025. 